\section{Salting by vacuum brine impregnation in nitrite-free lonza: effect on Enterobacteriaceae}

\author{
Annalisa Serio, ${ }^{1}$ \\ Clemencia Chaves-López, ${ }^{1}$ \\ Chiara Rossi, ${ }^{1}$ Paola Pittia, \\ Marco Dalla Rosa, ${ }^{2}$ \\ Antonello Paparella ${ }^{1}$
}

${ }^{1}$ Faculty of Bioscience and Technology

for Food, Agriculture and Environment,

University of Teramo, Teramo;

${ }^{2}$ Department of Agricultural and Food

Sciences, University of Bologna, Cesena

(FC), Italy

\begin{abstract}
Lonza is a traditional Italian meat product made from whole pork muscles, which is typically cured by dry salting. In this work, we study the effects of vacuum brine impregnation (VBI) as an alternative salting method on the survival of Enterobacteriaceae, in presence and in absence of nitrites. In comparison with the traditional brining process, VBI contributed to reducing the Enterobacteriaceae population on product surface but induced contamination of the inner muscle tissues. Our results suggest that the species isolated became adapted to processing conditions, and salt tolerance was species- or straindependent. This result is of particular importance for future applications of VBI in lonza manufacturing.
\end{abstract}

\section{Introduction}

Sodium nitrite is traditionally used in meat products for multiple purposes, and particularly for its antimicrobial, antioxidant and colour formation properties (Berardo et al., 2016). However, in the last decades, nitrite has been scrutinised by media, consumers and scientific community for its role in the formation of carcinogenic nitrosamines (Bouvard et al., 2015). Food products labelled as natural, organic, or preservative-free are showing sales success in the marketplace year after year (Sindelar and Houser, 2009), and for this reason nitrite reduction or elimination is of paramount importance for the food industry.

In manufacturing of whole muscles drycured meat products, salting, post-salting and ripening are sequentially applied. In traditional salting, nitrates are normally added to the curing salt mixture to delay spoilage and control microbial activity during storage. They also act as a source of nitrites if nitrate-reducing bacteria are present (Skovgaard, 1992) but also thanks to endogenous enzyme activity at low $\mathrm{pH}$ in a reducing environment. In the last years, vacuum brine impregnation (VBI) has been proposed as an alternative method for meat salting (Corzo and Bracho, 2007; Wang et al., 2016). This procedure can be considerably accelerated by tumbling in concentrated solutions, i.e. alternating immersion phases under vacuum and atmospheric pressure conditions (Deumier et al., 2003a, 2003b).

In addition to the biochemical changes induced by the endogenous enzymes, some microbial enzymes from a consortium of microorganims contribute to the ripening process, in particular from catalase negative cocci (CNC), yeasts and moulds. Many intrinsic and extrinsic factors influence the evolution of these microbial groups during meat ripening, with a strong selective pressure induced by salt penetration. Inadequate curing may cause the survival of different microbial groups that can be undesirable such as enterobacteria that are considered as quality-related organisms in cured meat products (Belletti et al., 2013). In fact, even though the environmental conditions do not favour Enterobacteriaceae, in particular Serratia spp. and Proteus spp. can grow throughout curing (Marin et al., 1996; Garcia et al., 2000). The survival of Enterobacteriaceae during the production of cured meats is not only relevant for product shelf-life, but also for food safety, as this family includes pathogens and biogenic amines producers (Suzzi and Gardini, 2003; Chaves-López et al., 2006). The aim of this work was to study Enterobacteriaceae population both in presence and in absence of nitrites during VBI salting of Italian lonza, a traditional meat product made from whole pork muscles that is typically cured by dry salting.

\section{Materials and Methods}

\section{Sampling treatment}

The deboned meat used for lonza manufacturing was obtained from pigs slaughtered 2 weeks before. Immediately after purchase, the pork loins (Longissimus dorsi) were frozen separately in an air-blast quick freezer at $-50^{\circ} \mathrm{C}$ for $4 \mathrm{~h}$ and then kept in a freezing chamber at $-18^{\circ} \mathrm{C}$ until use. Before treatment, whole loins were thawed at $4^{\circ} \mathrm{C}$ for $24 \mathrm{~h}$. Loins weight ranged from 2 to $2.3 \mathrm{~kg}$ for all tests. The brine was a water solution containing $20 \% \mathrm{NaCl}, 2 \%$ dex-
Correspondence: Antonello Paparella, Faculty of Bioscience and Technology for Food, Agriculture and Environment, University of Teramo, via R. Balzarini 1, 64100 Teramo, Italy.

Tel/Fax: +39.0861.266944.

E-mail: apaparella@unite.it

Key words: Enterobacteriaceae; Lonza; Vacuum brine impregnation; Nitrite.

Conflict of interest: the authors declare no potential conflict of interest.

Funding: Tecnolonza Project, funded by the Italian Ministry of Economical Development.

Received for publication: 19 July 2016.

Revision received: 3 October 2016.

Accepted for publication: 11 October 2016.

This work is licensed under a Creative Commons Attribution-NonCommercial 4.0 International License (CC BY-NC 4.0).

(C) Copyright A. Serio et al., 2017

Licensee PAGEPress, Italy

Italian Journal of Food Safety 2017; 6:6178

doi:10.4081/ijfs.2017.6178

trose, $1 \%$ saccharose, $0.1 \%$ ascorbate, and $0.1 \%$ mixed spices. When added, nitrates were used at $0.085 \%$ concentration. The brine was added in ratio of $2 \mathrm{~kg} / \mathrm{kg}$ (brine/meat).

Pork loins (30 kg per batch) were subjected to VBI treatment in trials with nitriteadded brine (NB) and without sodium nitrite (B) at $4^{\circ} \mathrm{C}$ for $20 \mathrm{~min}$, by using a pulsed vacuum tumbler (VM, Reggio Emilia, Italy). After tumbling, each batch was kept in a stainless steel wagon at $4^{\circ} \mathrm{C}$ for $16 \mathrm{~h}$ to favour salt diffusion. In the samples subjected to the traditional process, dry-curing was carried out at $5^{\circ} \mathrm{C}$ for 21 days. Both types of samples were stuffed into cellulose casing and subjected to drying ( 8 days, 15 to $17^{\circ} \mathrm{C}, 70$ to $90 \%$ humidity ratio) and curing (60 days, $14-15^{\circ} \mathrm{C}, 65$ to $85 \%$ humidity ratio). Three batches for each treatment were analysed.

\section{Sampling}

Sampling of three production batches was carried out at different process times (days): 0 (raw pork loin), 1 (salting), 15, 21 (end of salting), 21 (stuffing into casing), 36 (end of drying), 66 (ripening), 96 and 116 days.

\section{Microbiological analyses}

Analyses were performed after careful removal of surface moulds. First, the cellulose casing was washed with ethanol, then cut with a sterile knife, and removed by 
using sterile forceps. After that, surface (1.5 $\mathrm{cm})$ and core samples $(3.5 \mathrm{~cm}$ diameter $)$ were taken by means of a sterile knife.

Core and surface samples (10 g) were homogenized in a Stomacher Lab-Blender 400 (Seward Medical, London, UK) in 90 $\mathrm{mL}$ sterile saline solution. Decimal dilutions of the suspension were prepared in physiological solution, and Enterobacteriaceae were isolated and counted in Violet Red Bile Glucose Agar (Oxoid, Basingstoke, UK) at $37^{\circ} \mathrm{C}$ for $24 \mathrm{~h}$. Enterobacteriaceae isolates were identified with API 20 E (bioMérieux, Mercy L'Etoile, France).

\section{Growth response to sodium chloride}

To evaluate the isolates capability of growing under different concentrations of the additives used in lonza production, growth in Brain Heart Infusion (BHI, Oxoid) modified with different concentrations of $\mathrm{NaCl}$ (Oxoid) $(0,3,5,7$, and 10\%) was tested. First the experiment was performed in micro-scale: overnight cultures were centrifuged and washed twice in sterile saline solution, then $20 \mu \mathrm{L}$ were inoculated into $200 \mu \mathrm{L}$ of medium and optical density at $600 \mathrm{~nm}\left(\mathrm{OD}_{600}\right)$ was measured by means of Bioscreen C System (Labsystems Oy, Helsinki, Finland) during 48 h. The data obtained were modelled by means of Gompertz equation, modified by Zwietering et al. (1991). The experiment was repeated three times. To verify if the data obtained by Bioscreen reflected the behaviour of the strains in macro-scale, for some selected strains the previous experiments were performed in flasks containing $100 \mathrm{~mL}$ of modified medium, maintaining the same proportion of inoculum and time of incubation.

\section{Chemical and physical analyses}

$\mathrm{pH}$ values were measured by using a Mettler Toledo MP 220 pHmeter (Mettler, Toledo, Spain) on aqueous dispersions $(1: 10)$ of the samples. Water activity $\left(\mathrm{a}_{\mathrm{w}}\right)$ was measured by using a dew-point hygrometer Aqualab CX2 (Decagon Devices, Pullman, PA, USA).

\section{Statistical analysis}

One-way analysis of variance and least significant difference were used to analyse differences in mean values at 95 and $99 \%$ accuracy level.

\section{Results}

\section{Chemical and physical analyses}

Regarding $\mathrm{pH}$, no statistically significant differences among the samples were observed (data not shown). VBI treatments with or without nitrates were not significantly different as regards $\mathrm{a}_{\mathrm{w}}$, while significantly lower values were observed with respect to control (traditional process).

\section{Microbiological characteristics}

As evidenced in Table 1, in lonza samples subjected to the traditional dry-curing, the presence of Enterobacteriaceae was evident only on surface samples. In particular, the count was 2.9 Log colony forming unit $(\mathrm{CFU}) / \mathrm{g}$ at day 0 , decreased up to $1.70 \mathrm{Log}$ $\mathrm{CFU} / \mathrm{g}$ at the end of salting (day 21), increased again up to $2.9 \mathrm{Log} \mathrm{CFU} / \mathrm{g}$ after casing, and were below limit of detection in the following sampling times.

Pulsed VBI caused a count reduction between 1.0 and $1.9 \mathrm{Log} \mathrm{CFU} / \mathrm{g}$ on the product surface after one day of treatment for NB and B samples, respectively. During salting, NB samples showed a further reduction of $1 \mathrm{Log} \mathrm{CFU} / \mathrm{g}$ up to day 15 , and after that the count increased again and reached 2.7 Log CFU/g. On the contrary, in B samples, after an initial reduction of about $1.9 \mathrm{Log} \mathrm{CFU} / \mathrm{g}$, the count increased regularly up to $2.6 \mathrm{Log} \mathrm{CFU} / \mathrm{g}$ on product surface at day 21 and reached $3.2 \mathrm{Log}$ $\mathrm{CFU} / \mathrm{g}$ at day 21 in core samples.

For all treatments, the stuffing into casing increased the Enterobacteriaceae count on product surface. Starting from day 36 in traditional curing, and day 60 in both types of VBI samples (NB and B), Enterobacteriaceae were below limit of detection.

\section{Identification and characterisation of Enterobacteriaceae strains isolat- ed throughout lonza manufacturing}

To investigate the survival potential of Enterobacteriaceae during VBI treatment, a representative number of isolates was identified and characterized for the tolerance to different concentrations of $\mathrm{NaCl}$. A total of 40 strains was isolated from VBI treated samples. Table 2 shows the number of isolates of the different species identified, with a predominance of Enterobacter cloacae, followed by Serratia liquefaciens, Citrobacter spp., Serratia odorifera, and Escherichia coli. Other species such as Enterobacter aerogenes, Klebsiella ornithinolytica, Serratia marcescens and Proteus vulgaris were found at lower percentages. The latter species was isolated only after stuffing, while E. coli, Ser. odorifera, Ser. liquefaciens and Ent. aerogenes strains were isolated up to day 36 in the samples.

O.D. 600 data, corresponding to the Enterobacteriaceae strains growth in presence of each salt concentration, were analysed according the modified Gompertz equation. The predicted curves fitted well with the experimental points, and the regression coefficients of the curves obtained ranged from 0.95 to 0.98 .

Overall, the increase of $\mathrm{NaCl}$ levels influenced the $\mathrm{A}_{\max }$ and lag phase duration of the majority of the strains. As evidenced in Table 3, all the strains were able to grow at high $\mathrm{NaCl}$ percentages. In particular, levels of $7 \% \mathrm{NaCl}$ slightly increased the growth of Ser. liquefaciens and Ser. odorifera strains. Moreover, in presence of $10 \%$ $\mathrm{NaCl}$ all the strains of $E$. coli grew, reaching $\mathrm{OD}_{600}$ values up to 0.72 , while two Ser. marcescens and one $S$. liquefaciens strain reached $\mathrm{OD}_{600}$ values of 0.64 and 0.58

Table 1. Enterobacteriaceae (Log colony forming unit/g) in lonza samples at different times.

\begin{tabular}{|c|c|c|c|c|c|c|c|}
\hline & \multirow[t]{2}{*}{ Days } & \multicolumn{2}{|c|}{ Traditional dry-curing } & \multicolumn{2}{|c|}{ Pulsed VBI (20 min) NB } & \multicolumn{2}{|c|}{ Pulsed VBI (20 min) B } \\
\hline & & Surface & Core & Surface & Core & Surface & Core \\
\hline \multirow[t]{4}{*}{ Salting } & 0 & $2.9 \pm 0.3$ & nd & $3.3 \pm 0.2$ & nd & $3.2 \pm 0.3$ & nd \\
\hline & 1 & $2.9 \pm 0.1$ & nd & $2.3 \pm 0.2$ & $1.4 \pm 0.4$ & $1.3 \pm 0.2$ & $0.3+0.1$ \\
\hline & 15 & $2.7 \pm 0.2$ & nd & $1.1 \pm 0.1$ & $1.2 \pm 0.3$ & $2.0 \pm 0.2$ & $0.4 \pm 0.1$ \\
\hline & 21 & $1.7 \pm 0.2$ & nd & $2.7 \pm 0.1$ & $1.3 \pm 0.2$ & $2.6 \pm 0.2$ & $3.2 \pm 0.2$ \\
\hline \multirow[t]{2}{*}{ Drying } & 21 & $2.9 \pm 0.1$ & nd & $3.0 \pm 0.1$ & $1.3 \pm 0.3$ & $2.6 \pm 0.1$ & $3.2 \pm 0.1$ \\
\hline & 36 & nd & nd & $1.3 \pm 0.3$ & $2.1 \pm 0.1$ & $2.0 \pm 0.2$ & $2.6 \pm 0.1$ \\
\hline \multirow[t]{3}{*}{ Curing and ripening } & 60 & nd & nd & nd & nd & nd & nd \\
\hline & 90 & nd & nd & nd & nd & nd & nd \\
\hline & 120 & nd & nd & nd & nd & nd & nd \\
\hline
\end{tabular}

VBI, vacuum brine impregnation; NB, with nitrite-added brine; B, without sodium nitrite; nd, non-detectable (below limits of detection of the method employed). 
respectively, after 24 h. Ser. odorifera showed the lower lag phase duration at $10 \%$ $\mathrm{NaCl}$, while the most sensitive strains were those belonging to the species Ent. cloacae which reached $\mathrm{OD}_{600}$ values of 0.50 .

The most $\mathrm{NaCl}$ tolerant strains, belonging to Ser. liquefaciens, Ser. marcescens and E. coli species, were also evaluated in flasks at low $(0 \%, 3 \%)$ and high $(7 \%, 10 \%) \mathrm{NaCl}$ percentages (data not shown). Also in this case, differences were observed among the strains especially in the lag phase, probably due to a late stationary phase reached in the pre-culture or to specific strain behaviours. In particular, the cells grew vigorously in control and in the medium containing 3\% $\mathrm{NaCl}$ with a maximum growth value ranging from 0.61 to $0.84 \mathrm{OD}_{600}$ after a lag phase ranging from 0.45 to $1.30 \mathrm{~h}$. At high $\mathrm{NaCl}$ concentrations, the strains grew slowly at $7 \%$ after a lag phase ranging from 1.47 to $3.03 \mathrm{~h}$ and a maximum growth value of 0.4 $\mathrm{OD}_{600}$. At $10 \%$, only the strain C26S4 belonging to Ser. liquefaciens species, showed a maximum growth value of 0.75 $\mathrm{OD}_{600}$ after a lag phase of $4.21 \mathrm{~h}$, while the others had a maximum growth value between 0.28 and $0.31 \mathrm{OD}_{600}$.

\section{Discussion}

Salting is one of the most ancient and efficient preservation methods, especially for meats (Pittia and Paparella, 2015). Not only is the addition of salt important to reduce the $a_{w}$ below a tolerable level for spoilage microorganisms (Feiner, 2006), but it also regulates the activity of the endogenous enzymes involved in the development of the sensory properties of the final product (i.e. flavour, texture) (Martuscelli et al., 2015). In fact, salting increases lipid emulsification and protein dissolution in the meat, and gives unique sensory characteristics to cured meat products (Chiralt et al., 2001). In this work, the effect of pulsed VBI on the Enterobacteriacaeae population dur-

ing lonza production was studied.

Among the cured meat microbiota, Enterobacteriaceae are particularly sensitive to salt and normally grow starting from

Table 2. Identification of the strains isolated from vacuum brine impregnation-treated samples.

\begin{tabular}{|c|c|c|}
\hline Time of isolation (days) & Number of strains & Species \\
\hline 0 (raw meat) & $\begin{array}{l}1 \\
1 \\
1 \\
1\end{array}$ & $\begin{array}{c}\text { Ent. cloacae } \\
\text { Ser. liquefaciens } \\
\text { Ser. odorifera } \\
\text { E. coli }\end{array}$ \\
\hline 1 (salting) & $\begin{array}{l}1 \\
1 \\
1 \\
1 \\
2 \\
2\end{array}$ & $\begin{array}{l}\text { Ent. cloacae } \\
\text { Ent. aerogenes } \\
\text { Ser. marcescens } \\
\text { Ser. liquefaciens } \\
\text { Citrobacter spp. } \\
\quad \text { E. coli }\end{array}$ \\
\hline 15 (middle salting) & $\begin{array}{l}2 \\
1 \\
2\end{array}$ & $\begin{array}{c}\text { Ent. cloacae } \\
\text { Ser. odorifera } \\
\text { Citrobacter spp. }\end{array}$ \\
\hline 21 (end of salting) & $\begin{array}{l}1 \\
1 \\
2 \\
2 \\
1\end{array}$ & $\begin{array}{l}\text { Ent. cloacae } \\
\text { Ent. aerogenes } \\
\text { Ser. marcescens } \\
\text { Ser. odorifera } \\
\text { K. ornithinolytica }\end{array}$ \\
\hline 21 (after stuffing) & $\begin{array}{l}3 \\
1 \\
2 \\
1 \\
2 \\
1 \\
1\end{array}$ & $\begin{array}{c}\text { Ent. cloacae } \\
\text { Ser. liquefaciens } \\
\text { Ser. odorifera } \\
\text { K. ornithinolytica } \\
\text { Citrobacter spp. } \\
\text { E. coli } \\
\text { Proteus vulgaris }\end{array}$ \\
\hline 36 (drying) & $\begin{array}{l}1 \\
2 \\
1 \\
1\end{array}$ & $\begin{array}{c}\text { Ent. aerogenes } \\
\text { Ser. liquefaciens } \\
\text { Ser. odorifera } \\
\text { E. coli }\end{array}$ \\
\hline 66 days (ripening) & nd & - \\
\hline 96 days (ripening) & nd & - \\
\hline 116 days (ripening) & nd & - \\
\hline
\end{tabular}

Table 3. Growth parameters for the forty Enterobacteriaceae strains isolated from lonza samples, in presence of different sodium chloride concentrations (\%) in Bioscreen C System (Labsystems Oy, Helsinki, Finland).

\begin{tabular}{|c|c|c|c|c|c|c|c|c|c|c|c|}
\hline \multirow[t]{2}{*}{ Species } & \multirow[t]{2}{*}{ rains (n) } & \multicolumn{2}{|c|}{$0 \%$} & \multicolumn{2}{|c|}{$3 \%$} & \multicolumn{2}{|c|}{$5 \%$} & \multicolumn{2}{|c|}{$7 \%$} & \multicolumn{2}{|c|}{$10 \%$} \\
\hline & & $\begin{array}{c}\mathrm{A}_{\max } \\
\left(\mathrm{OD}_{600}\right)\end{array}$ & $\begin{array}{c}\lambda \\
\text { (hours) }\end{array}$ & $\begin{array}{c}\mathbf{A}_{\max } \\
\left(\mathbf{O D}_{600}\right)\end{array}$ & $\begin{array}{c}\lambda \\
\text { (hours) }\end{array}$ & $\begin{array}{c}\mathbf{A}_{\max } \\
\left(\mathbf{O D}_{600}\right)\end{array}$ & $\begin{array}{c}\lambda \\
\text { (hours) }\end{array}$ & $\begin{array}{c}A_{\max } \\
\left(\mathbf{O D}_{600}\right)\end{array}$ & $\begin{array}{c}\lambda \\
\text { (hours) }\end{array}$ & $\begin{array}{c}\mathbf{A}_{\max } \\
\left(\mathbf{O D}_{600}\right)\end{array}$ & $\begin{array}{c}\lambda \\
\text { (hours) }\end{array}$ \\
\hline Ent. cloacae & 8 & $0.94 \pm 0.18$ & $0.94 \pm 0.20$ & $0.76 \pm 0.08$ & $1.10 \pm 0.18$ & $0.79 \pm 0.13$ & $1.15 \pm 0.17$ & $0.80 \pm 0.16$ & $1.20 \pm 0.12$ & $0.50 \pm 0.10$ & $2.45 \pm 0.45$ \\
\hline Ent. aerogenes & 3 & $0.96 \pm 0.03$ & $1.00 \pm 0.30$ & $0.58 \pm 0.25$ & $1.00 \pm 0.31$ & $0.75 \pm 0.07$ & $1.26 \pm 0.40$ & $0.75 \pm 0.09$ & $1.28 \pm 0.38$ & $0.56 \pm 0.04$ & $2.00 \pm 0.20$ \\
\hline Ser. marcescens & 3 & $1.10 \pm 0.08$ & $0.55 \pm 0.08$ & $0.83 \pm 0.05$ & $1.29 \pm 0.06$ & $0.84 \pm 0.07$ & $1.26 \pm 0.31$ & $0.81 \pm 0.03$ & $1.18 \pm 0.2$ & $0.64 \pm 0.09$ & $2.15 \pm 0.3$ \\
\hline Ser. liquefaciens & 6 & $1.04 \pm 0.05$ & $1.58 \pm 0.45$ & $0.79 \pm 0.08$ & $2.31 \pm 1.15$ & $0.83 \pm 0.04$ & $2.45 \pm 1.1$ & $0.92 \pm 0.06$ & $2.00 \pm 0.45$ & $0.58 \pm 0.09$ & $3.45 \pm 1.00$ \\
\hline Ser. odorifera & 5 & $0.93 \pm 0.19$ & $1.49 \pm 0.12$ & $0.75 \pm 0.07$ & $1.29 \pm 0.19$ & $0.82 \pm 0.12$ & $1.41 \pm 0.25$ & $0.87 \pm 0.15$ & $1.20 \pm 0.30$ & $0.60 \pm 0.06$ & $1.44 \pm 0.62$ \\
\hline K.ornithinolytica & 3 & $0.97 \pm 0.03$ & $0.45 \pm 0.12$ & $0.70 \pm 0.27$ & $0.42 \pm 0.25$ & $0.73 \pm 0.04$ & $0.56 \pm 0.33$ & $0.73 \pm 0.05$ & $0.48 \pm 0.22$ & $0.55 \pm 0.02$ & $1.46 \pm 0.41$ \\
\hline Citrobacter spp. & 6 & $1.03 \pm 0.02$ & $1.24 \pm 0.19$ & $0.79 \pm 0.12$ & $1.43 \pm 0.26$ & $0.81 \pm 0.04$ & $1.45 \pm 0.59$ & $0.82 \pm 0.10$ & $1.55 \pm 0.39$ & $0.65 \pm 0.03$ & $3.32 \pm 1.23$ \\
\hline E. coli & 5 & $1.09 \pm 0.06$ & $1.29 \pm 0.31$ & $0.91 \pm 0.03$ & $1.41 \pm 0.51$ & $0.85 \pm 0.05$ & $2.33 \pm 0.26$ & $0.80 \pm 0.12$ & $1.12 \pm 0.47$ & $0.72 \pm 0.08$ & $2.43 \pm 1.05$ \\
\hline Proteus vulgaris & 1 & 1.27 & 0.50 & 1.33 & 1.19 & 1.03 & 1.12 & 0.65 & 1.59 & 0.69 & 2.23 \\
\hline
\end{tabular}

Ent., Enterobacter; Ser., Serratia; K., Klebsiella; E., Escherichia; $\mathrm{OD}_{600}$, optical density at $600 \mathrm{~nm}$; $\mathrm{A}_{\max }$ maximum growth value reached; $\lambda$, lag phase. Results are expressed as the mean and standard deviation of three replicates. 
$\mathrm{a}_{\mathrm{w}}$ value of 0.93 (Vilar et al., 2000). Mesophilic genera of Enterobacteriaceae such as Salmonella spp., Shigella spp. and certain Escherichia coli may cause severe diarrhoea, as well as the psychrotrophic Yersinia enterocolitica. In addition, other Enterobacteriaceae that are able to grow in meat products and cause spoilage, such as Serratia marcescens and Enterobacter cloacae, may also be of clinical concern (Lindberg et al., 1998).

In this study, a reduction of Enterobacteriaceae count after traditional salting was observed, although this microbial group was still able to grow on lonza surface up to day 30. Marin et al. (1996) reported the persistency of Enterobacteriaceae throughout the industrial manufacturing of dry-cured ham with a final $\mathrm{a}_{\mathrm{w}}$ value of 0.88 . These authors found that Leclercia adecarboxylata, K. pneumoniae and Ent. aerogenes were still present at the end of the process, whereas Ser. marcescens, Citr. freundii, Erwinia spp., Hafnia alvei, Edwarsiella spp., and Serratia spp. were detectable at the end of the salting process (40-45 days). As evidenced by our results, in comparison with the traditional dry-curing, pulsed VBI contributed to the reduction of the Enterobacteriaceae population on the product surface but was responsible of internal contamination. In fact, VBI induces mass transfer that involves external diffusion mechanisms and non-diffusional infiltration of solution into meat spaces occupied by occluded and/or dissolved gases prior to vacuum processing (Deumier et al., 2003a). Thus, it is possible that enterobacteria were infiltrated during the VBI treatment together with the brine, and then remained trapped inside the inner muscle tissues.

In our VBI treated samples, the Enterobacteriaceae were isolated only up to end of drying (day 36), with Ser. liquefaciens, Ser. odorifera, Ent. aerogenes, and E. coli being the dominant species at this stage of production and showing the best ability to grow at high $\mathrm{NaCl}$ concentrations. Although Ser. marcescens showed high $\mathrm{NaCl}$ tolerance, it was not isolated during the drying step, probably because product conditions, other than $\mathrm{NaCl}$ concentration, were determinant for their survival and/or growth in agar plates.

Jordan and Davies (2001) suggested that the addition of sodium chloride, rather than contributing to inhibition can reverse the inhibitory effect of lactate and enable growth under conditions of low $\mathrm{pH}$ and high lactate in E. coli O157:H7. Our results suggest that the species we isolated became adapted to processing conditions, showing salt tolerance that can be species- or strain- dependent. Ser. liquefaciens is a psychrotrophic proteolytic enterobacterium that can survive under adverse conditions and can be isolated from several cured meats even in the last period of ripening (Castaño et al., 2002; Lyhs et al., 1998).

From the results obtained in the present study, it may be concluded that many Enterobacteriaceae strains isolated from Italian lonza can show high tolerance to sodium chloride.

\section{Conclusions}

The survival of the Enterobacteriaceae species during meat salting is a health risk of particular importance, because this family includes pathogens and species capable of producing biogenic amines. In our study, in contrast with what might be assumed on the basis of $\mathrm{a}_{\mathrm{w}}$ decrease before drying, VBI salting of nitrite-free lonza was able to induce micro-ecological changes that favoured the survival of Enterobacteriaceae, although these microorganisms were never isolated from final products. This result is of particular importance in the perspective of a possible industrialisation of the VBI process for manufacturing nitrite-free meat products. Further studies will be needed to investigate solutions for mitigating the risk of enterobacteria survival during VBI processing.

\section{References}

Belletti N, Garriga M, Aymerich T, BoverCid S, 2013. Inactivation of Serratia liquefaciens on dry cured ham by high pressure processing. Food Microbiol 35:34-7.

Berardo A, De Maere H, Stavropoulou DA, Rysman T, Leroy F, De Smet S, 2016. Effect of sodium ascorbate and sodium nitrite on protein and lipid oxidation in dry fermented sausages. Meat Sci 121:359-64.

Bouvard V, Loomis D, Guyton KZ, Grosse Y, Ghissassi FE, Benbrahim-Tallaa L, Guha N, Mattock H, Straif K, International Agency for Research on Cancer Monograph Working Group, 2015. Carcinogenity of consumption of red and processed meat. Lancet Oncol 16:1599-600.

Castaño A, García Fontán MC, Fresno JM, Tornadijo ME, Carballo J, 2002. Survival of Enterobacteriaceae during processing of Chorizo de cebolla, Spanish fermented sausage. Food Control 13:107-15.
Chaves-López C, De Angelis M, Martuscelli M, Serio A, Paparella A, Suzzi G, 2006. Characterization of the Enterobacteriaceae isolated from an artisanal Italian ewe's cheese (Pecorino Abruzzese). J Appl Microbiol 101:35360.

Chiralt A, Fito P, Barat JM, 2001. Use of vacuum impregnation in food salting process. J Food Eng 49:141-51.

Corzo O, Bracho N, 2007. Determination of water effective diffusion coefficient of sardine sheets during vacuum pulse osmotic dehydration. LWT-Food Sci Technol 40:1452-8.

Deumier F, Bohuon P, Trystram G, Saber N, Collignan A, 2003a. Pulsed vacuum brining of poultry meat: Experimental study on the impact of vacuum cycles on mass transfer. J Food Eng 58:75-83.

Deumier F, Gilles T, Collignan A, Guédider L, Bohuon P, 2003b. Pulsed vacuum brining of poultry meat: interpretation of mass transfer mechanisms J Food Eng 58:85-93.

Feiner G, 2006. Meat products handbook practical science and technology. CRC, Boca Raton, FL, USA.

Garcia C, Martin A, Timon ML, Cordoba JJ, 2000. Microbial populations and volatile compounds in the "bone taint" spoilage of dry cured ham. Lett Appl Microbiol 30:61-6.

Jordan KN, Davies KW, 2001. Sodium chloride enhances recovery and growth of acid-stressed E. coli O157:H7. Lett Appl Microbiol 32:312-5.

Lindberg AM, Ljungh A, Ahrne S, Löfdahl S, Molin G, 1998. Enterobacteriaceae found in high numbers in fish, minced meat and pasteurised milk or cream and the presence of toxin encoding genes. Int J Food Microbiol 39:11-7.

Lyhs U, Bjorkroth J, Hyytia E. Korkeala H, 1998. The spoilage flora of vacuumpackaged, sodium nitrite or potassium nitrate treated, cold-smoked rainbow trout stored at 4 degrees $\mathrm{C}$ or 8 degrees C. Int J Food Microbiol 45:135-42.

Marin ME, Carrascosa AV, Cornejo I, 1996. Characterization of Enterobacteriaceae strains isolated during industrial processing of dry-cured hams. Food Microbiol 13:375-82.

Martuscelli M, Lupieri L, Chaves-López C, Mastrocola D, Pittia P, 2015. Technological approach to reduce $\mathrm{NaCl}$ content of traditional smoked dry-cured hams: effect on quality properties and stability. J Food Sci Technol 52:777182.

Pittia P, Paparella A, 2015. Safety by control of water activity: drying, smoking, salt or sugar addition. In: Lelieveld $\mathrm{H}$, 
Prakash V, Keener L, Kopper G, Astley $\mathrm{S}$, Braun S, eds. Regulating safety of traditional and ethnic foods. Elsevier Academic Press, Amsterdam, The Netherlands, pp. 7-28.

Sindelar JJ, Houser TA, 2009. Alternative curing systems. In: Tartè $\mathrm{R}$, ed. Ingredients in meat products: properties, functionality and applications. Springer Science, New York, NY, pp 379-405.

Skovgaard N, 1992. Microbiological aspects and technological need: technological needs for nitrates and nitrites. Food Addit Contam 9:391-7.

Suzzi G, Gardini F, 2003. Biogenic amines in dry fermented sausages: a review. Int J Food Microbiol 88:41-54.

Vilar I, García Fontán MC, Prieto B, Tornadijo ME, Carballo J, 2000. A survey on the microbiological changes during themanufacture of dry-cured Iacón, a Spanish traditional meat product. J Appl Microbiol 89:1018-26.
Zwietering MH, De Koos JT, Hasenack BE, De Witt JC, Van't Riet K, 1991. Modelling of bacterial growth as a function of temperature. Appl Environ Microbiol 57:1094-101.

Wang Z, Xu W, Kang N, Shen Q, Zhang D, 2016. Microstructural, protein denaturation and water holding properties of lamb under pulse vacuum brining. Meat Sci 113:132-8. 